\author{
Jurgita Cvilikaitè \\ Vytauto Didžiojo universitetas, Lietuva
}

\title{
TANDEMINIS KALBU MOKYMASIS: ELEMENTAI, PRINCIPAI IR PERSPEKTYVOS
}

\begin{abstract}
Santrauka. Straipsnyje pristatomas tandeminis kalbu mokymosi metodas, apibrèžiami svarbiausi jo elementai - tandemo partneriu vaidmuo, užsièmimu forma, medžiaga. Tandeminis kalbu mokymasis vyksta tarp dvieju gimtakalbiu, kurie mokosi vienas kito kalbos. Sis metodas gristas autonomiškumo ir abipusiškumo principais ir lemia kitoki kalbu mokymąsi, kuri organizuoja, planuoja patys tandemo partneriai. Mokydamiesi kartu jie plètoja užsienio kalbos, savo gimtosios kalbos, tarpkultūrinès komunikacijos, mokymosi bendradarbiaujant, mokymosi mokytis ir kitas svarbias kompetencijas. Straipsnyje aprašomi apklausos, kuria buvo siekiama išsiaiškinti, ar žinomas tandeminio mokymosi metodas Lietuvoje, rezultatai. Be to, šia apklausa buvo siekiama sužinoti, ar respondentus sudomintu toks mokymosi metodas, ar jis motyvuotu pagilinti turimas užsienio kalbos žinias arba paskatintu mokytis naujos užsienio kalbos. Apklausos rezultatai rodo, kad tik penktadalis respondentu žino, kas yra tandeminis mokymasis. Daugiau negu trečdalis respondentu abejoja, ar šis metodas galètu išpopuliarèti Lietuvoje, tačiau tandemu sutiktu mokytis dauguma respondentu. Paprašyti ivardyti labiausiai jiems priimtina kalbu mokymosi būda, dauguma nurodè mokymąsi privačiai arba grupeje ir tik mažuma minejo savarankiška mokymąsi. Tarp priežasčiu, kurjos trukdo tobulintis ar mokytis naujos kalbos, išryškejjo dvi - pinigu ir laiko stygius. Sie ir kiti apklausos rezultatai liudija, kad Lietuvoje tandeminio mokymosi metodas iš tiesu nèra gerai žinomas, retai taikomas ir mažai viešinamas. Nors teigiama, kad tandeminis mokymasis yra pagalbinis kalbu mokymosi metodas, jis gali būti naudingas ir žmonèms, norintiems mokytis kalbu, ir mokslininkams, tyrinejjantiems besimokančiuju elgsena ivairiose mokymosi situacijose, motyvacijos problematika, mokymosi pasiekimus ir panašias temas.
\end{abstract}

Pagrindinès sąvokos: tandeminis mokymasis, tandemo partneriai, autonomiškumas, abipusiškumas, užsienio kalbos mokymasis.

\section{Ivadas: tandeminio mokymosi apibrèžimas, elementai ir principai}

Tandeminis mokymasis dažnai apibrèžiamas kaip dvieju gimtakalbiu susitarimas darniai bendradarbiauti siekiant padèti vienas kitam tobulinti užsienio kalbos igūdžius (Appel ir Mullen, 2000, p. 291, Brammerts, 1996, p. 10, O'Rourke, 2005, p. 434, Stickler, 2008, p. 75). Be gilinamu užsienio kalbos igūdžiu taip pat minima, kad tokiu bendravimu siekiama ir susipažinti, sužinoti apie partnerio kultūrą, o galbūt igyti kitu igūdžiu, pavyzdžiui, reikalingu ju profesineje veikloje (Stickler, 2008, p. 75, Brammerts, 1996, p. 10). Vis dèlto nepakanka tandemini kalbu mokymosi metodą apibrèžti vienu ar dviem sakiniais. Čia svarbu aprašyti mokymosi proceso dalyvius, mokymosi formą ir turini.

Pagrindiniai tandeminio mokymosi veikèjai yra du - vadinamieji tandemo partneriai, kurie dažniausiai mokosi vienas kito gimtosios kalbos. Partneriai gali būti ir negim- 
takalbiai, tačiau jie privalo labai gerai mokèti užsienio kalbą, turi būti igudę tos kalbos vartotojai.

Mokymosi (susitikimo, užsièmimo ar kitokio bendravimo) metu tandemo partneriai atlieka du vaidmenis. Dali užsièmimo vienas partneris yra mokinys, o kitas - mokytojas, paskui jie pasikeičia vaidmenimis. Terminai „mokinys" ir "mokytojas" čia vartojami salygiškai, nes mokantis poroje tokie santykiai nèra ivardijami, o juo labiau formalizuojami. Mokslineje literatūroje galime rasti ir kitu terminu: "tandemo partneriai", "besimokantysis ir mentorius" (Donaldson ir Kötter, 1999, p. 70), "mokinys / studentas ir kalbos ekspertas" (Vassallo ir Telles, 2006, p. 6), „partneriai, ekspertai-informantai" (Stickler, 2008, p. 75).

Idealioje tandeminio mokymosi situacijoje neturètu egzistuoti trečiasis, formalusis, veikèjas - mokytojas ar dèstytojas, tad nèra ir iprasto vertinimo bei kitu formaliam mokymuisi būdingu elementu. Tačiau tai nereiškia, kad profesionalūs kalbos mokytojai šiuo atveju nebereikalingi, tik pabrèžiama, kad mokytojo pozicija tokiame mokymosi procese kinta, pereina i alternatyvu konsultanto vaidmeni (Stickler, 2008, p. 71). Mokytojams dažnai tenka koordinatoriaus, vadybinès ir kalbinès paramos teikejjo vaidmuo. Teigiama, kad visose autonomiško mokymosi fazèse partneriams turi būti pasiūlyta parama, parodyta, kaip planuoti, vertinti savo mokymosi veiklas, kaip pasirinkti tinkama problemu sprendimu strategija ir kt. (Little, 1996, p. 27, Stickler, 2008, p. 69). Būtina pabrèžti, kad tandeminis mokymasis yra autonomiško mokymosi metodas, todèl mokytojo ar kalbininko profesinis vaidmuo yra minimalus.

Tandeminio mokymosi forma - be privalomu dvieju partneriu - yra visiškai laisva, nulemta pačiu partneriu noru, galimybiu ir apsisprendimo. Partneriai renkasi užsièmimo laiką, trukmę, tempa, vietą ir paties mokymosi pobūdi. Ju susitikimo vieta gali būti bendrabučio kambarys, mègstama kavinè, universiteto koridorius, parkas ir daugybè kitu jiems maloniu aplinku. Jie taip pat gali nuspręsti mokytis virtualiai: susirašinèti, bendrauti pokalbiu kambariuose ar forumuose, naudodamiesi „Skype" ar kita programa, užsiregistravę specialiai tandeminiam mokymuisi sukurtuose tinkluose arba tiesiog socialiniuose tinkluose. Taigi bendravimo galimybiu yra daug, jos neapsiriboja vien rašytiniu bendravimu, o šiuolaikinès technologijos suteikia gyvo pokalbio su partneriu, gyvenančiu kad ir kitame pasaulio krašte, galimybę. Vis dèlto iš pateiktu pavyzdžiu galime išskirti du tandeminio mokymosi porūšius pagal darbo terpę: "gyvas" (ang. faceto-face) ir virtualus (ang. e-tandem, email tandem, teletandem). Little'as (Little, 1996, p. 23) pateikia mišraus tandeminio mokymosi pavyzdi, kur partneriai bendraudavo sinchroniškai (kalbėdavosi telefonu) ir asinchroniškai (rašydavo elektroninius laiškus).

Mokytis tandemu galima ne tik poromis, bet ir organizuojant grupiu tandemus, tad pagal besimokančiuju skaičiu galimi tandemo kursai ir individualus tandeminis mokymasis (Stickler, 2008, p. 70, Vassallo ir Telles, 2006, p. 3-4). Pagal tai, kas organizuoja tandemini mokymąsi, skiriamas institucinis ir individualus tandemas (Stickler, 2008, p. 70, Vassallo ir Telles, 2006, p. 7). Pirmuoju atveju tandemini mokymąsi organizuoja ir koordinuoja tam tikra institucija, mokymo istaiga, o antruoju - tandeminis mokymasis vyksta savanorišku susitarimu tarp dvieju asmenu, greičiausiai nesusijusiu su jokia institucija.

Trečiasis svarbus tandeminio mokymosi elementas yra mokymosi turinys, kuris yra lankstus ir aktualus besimokančiajam. Bendraudami tandemo partneriai patys pasirenka juos dominančias temas, todèl išvengiama formaliai primetamo mokymosi 
turinio problemos. Jeigu tema nusibodo, galima ja keisti ir kalbètis apie tai, kas aktualu tuo metu. Mokydamiesi partneriai susipažista, domisi vienas kitu, susidraugauja, o tai garantuoja sẻkminga šio tandemo tęstinumą. Keisdamiesi nuomonèmis, patirtimi partneriai turi domètis, o kartu ir informuoti vienas kita apie save ir savo aplinką (pomėgius, savo miestus, šalis, tradicijas). Nejučiomis jie vysto šiuolaikiniam žmogui taip reikalinga tarpkultūrinę kompetencija, nes sužino apie partnerio kultūrą, tradicijas, kalbą ir daug kitu dalyku.

\section{Tandeminio mokymosi principai}

Tandeminis mokymasis yra grindžiamas dviem esminiais principais - autonomiškumu ir abipusiškumu (Brammerts, 1996, p. 11-12, Stickler, 2008, p. 75, O’Rourke, 2005, p. 434, Vassallo ir Telles, 2006, p. 6-8, Appel ir Mullen, 2000, p. 292, Donaldson ir Kötter, 1999, p. 69). Little teigia (Little, 1996, p. 23), kad besimokantieji tampa autonomiškais tada, kai sąmoningai prisiima atsakomybę už savo mokymąsi ir nuolatos deda pastangas suvokti, ko, kodèl, kaip ir ar sékmingai jie mokosi. Tad pagal autonomiškumo principa tandemo partneriai privalo patys kontroliuoti savo mokymosi procesą. Autonomiškuma galime interpretuoti ivairiai: nuo susitarimo dèl laiko, vietos, mokymosi medžiagos pasirinkimo iki asmeninès atsakomybès už tandemini mokymąsi. Vassallo ir Telles teigimu, šis principas kontroliuoja partneriu atsakomybės ir itakos partnerio mokymosi procesui lygius (Vassallo ir Telles, 2006, p. 8). Tandemo partneriai, kurie besimokydami yra ir mokiniai, ir mokytojai, jaučia dvigubą atsakomybę: jie tampa atsakingi ne tik už savo mokymosi rezultatus, bet ir už savo partnerio užsienio kalbos mokymosi sẻkmę.

Abipusiškumo principas reiškia, kad abieju tandemo partneriu inašas i mokymąsi yra vienodas. Vadinasi, užsiemimu metu partneriai siekia išlaikyti balansą ir sutaria pusę užsièmimo bendrauti, rašyti, skaityti viena kalba, o kitą - kita. Vassallo ir Telles teigia, kad šis esminis tandeminio mokymosi elementas (t. y. kalbu nepainiojimas užsièmimo metu) nèra pakankamai pabrèžiamas. Ju tvirtinimu, būtent šis praktinis elementas skatina tandemo partneri kalbèti užsienio kalba, isigilinti ir isitraukti i užduotis (Vassallo ir Telles, 2006, p. 5-6). Naudos iš mokymosi tandemu bus mažai, jei tandemo partneriams bus lengviausia susišnekèti trečiaja kalba ir jie tą dažnai darys.

Brammerts (Brammerts, 1996, p. 10-11) teigia, kad susitikimo laikas turi būti vienodai paskirstomas ne tik kalboms. Partneriai tiek pat energijos privalo skirti pasiruošimui, kad mokymasis būtu prasmingas, efektyvus. Čia pasitvirtina gerai žinomas posakis: „Elkis su kitu taip, kaip norètum, kad su tavimi elgtusi”. Tad abipusiškumo principas lemia tandemo sèkmę, nes abu partneriai isipareigoja dirbti kartu ir padeti vienas kitam.

\section{Tandeminio mokymosi nauda}

Reikia pripažinti, kad tandeminis mokymosi metodas negali visiškai pakeisti paskaitu, kursu ar kitu formalaus mokymosi formu, tačiau jas efektyviai papildo. Kaip teigia Brammerts (1996, p. 10), tandeminis mokymasis "atlieka panašią funkcija kaip savarankiškas ruošimasis ar papildomas darbas namuose, mokymasis užsienio kalbos iš laikraščiu, knygu, radijo laidu, televizijos programu ar vaizdo irašu, mokymasis 
bendraujant su gimtakalbiais per viešnagę užsienyje ar bendravimas su susirašinejjimo draugu". Nors tandemini mokymąsi suvokiame kaip pagalbini, alternatyvu, jo nauda yra akivaizdi ne tik tandemo partneriams, bet ir institucijoms, koordinuojančioms tandemini mokymąsi, kalbu pedagogams ir tyrèjams, kurie domisi kalbu mokymo(si) metodologijomis, ju poveikiu besimokančiuju elgsenai, mokymosi pasiekimais ir kt. Metodo specifika lemia ir tokius būtinus paminèti privalumus, kaip tiesioginis praktinis žiniu pritaikymas bendraujant su gimtakalbiu, metalingvistinis sąmoningumas, dèmesys gimtajai kalbai, tarpkultūrinès komunikacijos plètojimas.

Akivaizdu, kad svarbiausia nauda, kurią gauna tandemo partneriai, - užsienio kalbos praktika ir žinios, nes toks yra pagrindinis tandeminės partnerystès tikslas. Tandeminis mokymasis sudaro salygas visiems kalbos vartojimo aspektams pagilinti (Kabata ir Edasawa, 2011, p. 104, Kawaguchi ir Di Biase, 2009, p. 293). Nuo pasirinktos mokymosi formos priklauso, kas bus tobulinama: tik rašymas ir skaitymas (pavyzdžiui, tandemo elektroniniais laiškais atveju), o gal kalbejjimo ir skaitymo igūdžiai.

Svarbus tandeminio mokymosi privalumas yra tas, kad partneriai tampa metalingvistiškai sąmoningi (O'Rourke, 2005, p. 433). Metalingvistinio sąmoningumo jie siekia ivairiais būdais: prasmingai bendraudami tarpusavyje, kreipdami dèmesi i ivairias kalbos formas ar aptardami tandemo kalbu panašumus ir skirtumus, o ypač atlikdami mokytojo vaidmeni, kai patys turi paaiškinti gimtosios kalbos ypatumus, vertinti ir pataisyti partnerio kalba. Taip, anot Alonso (Alonso, 2012, p. 232), tandemo partneriai tampa ne tik sąmoningesni, bet ir autonomiškesni.

Bendraudamas su tandemo partneriu gimtaja kalba ir siekdamas palengvinti jo mokymąsi, besimokantysis yra priverstas kitaip pažvelgti i savo gimtaja kalba, pastebèti tai, ką būtina perduoti kitiems, kas yra ypatinga, kas panašu i kitas kalbas. Todèl mokantis tandemu ugdoma labai svarbi kompetencija - komunikavimas gimtaja kalba.

Kaip buvo minèta, tandeminis mokymasis vyksta ne tik siekiant išmokti partnerio kalba, bet ir sužinoti apie jo šali ir kultūrą. Taigi besimokantieji mokosi ne tik taisyklingu kalbos formu, žodžiu bei fraziu, bet ir sužino kontekstus, kada tas formas ir žodžius galima vartoti. Vadinasi, tarpkultūrinès kompetencijos plètojimas yra kitas didžiulis šio metodo privalumas. Tai nauda ne tik tandemo partneriams, bet ir ju mokytojams, kuriems, anot Polisca (Polisca, 2011, p. 330), kultūrinio sąmoningumo ugdymas dažnai tampa iššūkiu, papildomu darbu mokant kalbos.

Greta tobulinamu užsienio kalbos žiniu, tarpkultūrinès ir metalingvistinès kompetenciju tandemo partneriai plètoja kitus igūdžius, kurie nèra tiesioginiai tandeminio mokymosi tikslai, tačiau ne mažiau naudingi. Tandemu partneriai perpranta mokymosi bendradarbiaujant ypatumus, tampa savarankiškesni ir labiau pasitikintys savimi.

Kaip buvo minèta, autonomiškumas yra vienas svarbiausiu tandeminio mokymosi principu. Tandemo partneriai turi savarankiškai planuoti, stebèti ir vertinti savo bei partnerio mokymąsi. O remiantis abipusiškumo principu, tokius sprendimus abu priima lygiaverčiai ir savarankiškai. Taigi partneriams suteikiama galimybè tapti autonomiškais bendradarbiais (Stickler, 2008, p. 19, Kawaguchi ir Di Biase, 2009, p. 293, Alonso, 2012, p. 232).

Būtina paminèti ir kitas kompetencijas, kurias gali igyti besimokantieji tandemu: mokymosi mokytis, technologiju išmanymo, laiko organizavimo, problemu sprendimo, informacijos paieškos ir apdorojimo, komandinio darbo ir kitos. Daugelis šiu 
kompetenciju yra susijusios ir turi itakos viena kitai. Pavyzdžiui, Brammerts (1996, p. 12) teigia: "Kuo geriau partneriai bendradarbiauja tenkindami savo ir partnerio mokymosi poreikius, tuo didesnè tikimybè, kad jie išplètos igūdžius, kuriu prireiks savarankiškose situacijose ateityje, pavyzdžiui, gyvenant užsienyje."

Mokymasis tandemu nèra darbas, jis nesunkus ir nenuobodus, kaip dažniausiai galvojama apie tradicini mokymąsi. Taigi tandeminis mokymasis teikia teigiamu emociju, bendravimo malonuma, pagaliau laisvę pasitraukti, jeigu tandemas nepateisina lūkesčiu ar sukelia neigiamu emociju. Labai svarbu ir tai, kad tandeminio mokymosi situacijoje partneriai yra lygiaverčiai, todèl tai didina ju savivertę ir motyvacija mokytis toliau, siekti užsibrèžtu tikslu.

Iš tandeminio mokymosi naudos gali turèti ir kalbu mokytojai bei taikomosios lingvistikos specialistai. Pastarieji igyja galimybę ivairiais aspektais tyrinèti ši idomu užsienio kalbu mokymosi kontekstą, analizuoti besimokančiuju mokymosi parametrus natūraliame komunikacijos kontekste. Kalbu mokytojai tandeminiu mokymusi gali sudominti, motyvuoti mokinius mokytis savarankiškai, gilinti pamokose igytas žinias. Be to, tai puiki galimybè pasiūlyti mokiniams pritaikyti turimas žinias bendraujant su gimtakalbiais, taip pat paskatinti juos mokytis bendradarbiaujant ir tapti savarankiškesnius (Vassallo ir Telles, 2006, p. 9-10).

\section{Tandeminio mokymosi privalumai kitų metodu atžvilgiu}

Vienas ryškiausiu tandeminio mokymosi privalumu yra mokymosi medžiagos ir aplinkos autentiškumas. Tandeminis kalbos mokymasis vyksta bendradarbiaujant su gimtakalbiu, kuris partneri gali pataisyti ar padèti teisingai reikšti mintis. Gimtakalbio padedamas besimokantysis gali koreguoti savo tarti, išsiaiškinti gramatines konstrukcijas, išmokti naudingos leksikos, o svarbiausia - suvokti jos vartojimo kontekstą. Asmeniškas, tikslingas ir tiesioginis partneriu bendravimas yra ne kas kita, kaip galimybè pritaikyti užsienio kalbos žinias natūralioje, taigi ir autentiškoje aplinkoje. Manoma, kad komunikavimas užsienio kalba su gimtakalbiu ar igudusiu kalbos vartotoju kelia mažiau baimès ir nerimo negu kiti mokymosi būdai (Stickler, 2008, p. 16).

Labai patraukli tandeminio mokymosi savybė yra jo lankstumas. Tai ne tik laisvas turinys, bet ir mokymosi terpè bei forma. Kaip jau buvo minèta, tandemo partneriai patys renkasi temas pokalbiams, susitikimu pobūdi (susirašinejjimas, gyvi pokalbiai, bendravimas internetu ir t. t.). Mokymasis tandemu gali vykti savarankiškai arba būti integruotas i mokymosi programą kaip pagalbinè priemonè, gali vykti tik tarp dvieju partneriu arba tarp grupiu, su kalbos specialistu ar be jo, gali trukti trumpai arba ilgai.

Tandeminis mokymasis yra labai motyvuojantis mokymosi metodas. Pirma, motyvuoja tai, kad bendraujama ir mokomasi su gimtakalbiu, vadinasi, patikimu kalbos šaltiniu. Mokymasis su gimtakalbiu motyvuoja ir dèl to, kad, anot Brammerts (Brammerts, 1996, p. 11), abu tandemo partneriai žino, ką reiškia būti mokiniu, todèl jautriau ir kantriau reaguoja i partnerio daromas klaidas. Antra, bendraujant su gimtakalbiu iš karto žinias galima pritaikyti praktiškai ir niekas nekeliama itampos privalomais žiniu patikrinimais, reikalavimu vykdymais ir panašiai. Trečia, minètas metodo lankstumas taip pat turi itakos besimokančiuju motyvacijai. Motyvacija didina ir technologiju naudojimas, nes tai idomu, modernu ir ypač artima šiuolaikinei jaunajai kartai. Pagaliau motyvacijos varomaja jèga tampa pats abipusiškumo 
principas: iš partnerio gausi tik tiek, kiek pats esi pasiruošęs jam atiduoti (Vassallo ir Telles, 2006, p. 17-18).

Dar vienas idomus tandeminio mokymosi ypatumas, kuri vertètu paminèti ir kuris gali pasirodyti gana paradoksalus, yra socialumo, individualumo skatinimas. Vassallo ir Telles teigimu (Vassallo ir Telles, 2006, p. 11-12), klasèje mokiniai ar studentai turi daug galimybiu bendrauti, tačiau mažai dèmesio skiriama ju individualiam mokymosi stiliui ir besimokančiojo autonomijai. Privačios pamokos metu, atvirkščiai, mokymasis yra individualizuotas, tačiau nukenčia socialinė kalbos mokymosi dimensija. Tandeminis mokymasis kyla iš partneriu poreikiu ir susidomejjimo, tad galima teigti, kad toks mokymosi metodas yra orientuotas i besimokantiji. Kita vertus, tandeminis mokymasis kyla iš partneriu bendravimo, todèl yra orientuotas ir i mokymosi eigos socialuma.

\section{Tandeminio mokymosi trūkumai}

Susidomejusieji tandeminio mokymosi privalumais gali susidurti su tam tikromis kliūtimis. Pirmiausia, kad susidarytu tandemas, reikia susirasti partneri. Pažangios komunikacijos technologijos suteikia galimybiu bendrauti toliausiuose kraštuose gyvanantiems žmonéms. Be to, dèl žmoniu mobilumo kitakalbi galima sutikti ir savame mieste. Kita vertus, negana vien susirasti tandemo partneri. Reikia susirasti toki, kuris norètu mokytis kalbos ir būtu pasirengęs padèti kitam. Taigi būtina surasti motyvuota, susidoméjusi, brandu asmeni, kuris nenutrauktu bendradarbiavimo po keliu susitikimu. Little teigia (Little, 1996, p. 28), kad besimokantieji tandemu turi būti jau pasiekę pakankamą savarankiškumo lygi, kitaip jiems bus sunku ir pradèti, ir tęsti tandemini mokymąsi. Didžiausia tikimybè susirasti tinkama partneri yra tandeminiam mokymuisi skirti interneto tinklai (pavyzdžiui, Tandem-Server Bochum, Tandem City, International Tandem Network, babelyou, projekto Seagull tinklalapio partnerio paieškos paslauga ir kt.).

Kita problema, su kuria gali susidurti tandemu jau bendradarbiaujantys partneriai, yra mokymosi medžiaga. Mokantis kalbos dalyko turini sudaro ne tik pasirinktos temos, bet ir leksinis bei gramatinis kalbos turinys. Viena vertus, programu nesuvaržyti tandemo partneriai turi nuostabią galimybę išmokti "gyvos" kalbos, kitaip sakant, gimtakalbio vartojamos leksikos ir tik reikalingiausiu gramatiniu konstrukciju. Kita vertus, šiuo atžvilgiu galima nujausti tam tikrą pavoju, kuris gali kilti dèl dvieju priežasčiu. Pirma, neturintis filologinio išsilavinimo tandemo partneris gali tiesiog nesugebèti paaiškinti tam tikru leksiniu ir gramatiniu kalbos aspektu. Partneriams gali kilti keblumu išplètoti pasirinktą pamokos temą tiek, kad būtu juntama konkreti lingvistinè nauda. Antra, reikia pripažinti, kad egzistuoja grèsmé išmokti arba išmokyti netaisyklingos gramatikos arba nevartotinos leksikos. Tačiau tai jau nebe šio straipsnio objektas.

Dèl minètu priežasčiu pasiteisina tandeminiam mokymuisi skirti projektai ir ju teikiama medžiaga. Tandemo partneriai patys gali rinktis tematika, o paruoštoje medžiagoje rasti gaires, apie ką kalbètis, kokius klausimus užduoti, kaip ivairiau organizuoti susitikimą. Projektai gali suteikti ir kalbinę, pedagoginę pagalbą. Pavyzdžiui, Seagull projekto tinklalapyje yra ne tik pamoku planai, bet ir kiekvienai pamokai skirta medžiaga, metodologiniai paaiškinimai, kaip geriau atlikti užduotis ir ko jomis mokoma, kurie igūdžiai tobulinami. Be to, metodologinèje medžiagoje 
minimaliai primenama ta gramatika, kurią tandemo partneris turètu mokèti, norèdamas bendrauti konkrečia tema.

\section{Apklausos rezultatai}

Šioje straipsnio dalyje pristatomi 2014 m. kovo-balandžio mènesiais internetu viešai vykdytos apklausos apie tandemini mokymąsi rezultatai ${ }^{40}$. Apklausos metodas internetu pasirinktas dèl jo lankstumo. Internetu lengviau pasiekti respondentus, o suformulavus tinkamus klausimus per trumpa laiką galima surinkti reikalingus duomenis apie respondentus ir gauti atsakymus i rūpimus klausimus. Apklausa buvo siekiama išsiaiškinti, kiek tandeminio mokymosi metodas yra žinomas Lietuvoje. Kitas apklausos tikslas - sužinoti, ar respondentus sudomintu toks mokymosi metodas ir ar jis motyvuotu pagilinti užsienio kalbos žinias arba mokytis naujos užsienio kalbos. Apklausoje dalyvavo 149 respondentai, iš ju - 119 moteru ir 30 vyru. Didžiaja respondentu dali sudarè jauni 21-30 metu (109 respondentai) ir 10-20 metu (29 respondentai) žmonès. 31 proc. respondentu nurodè turi vidurini išsilavinima, 26 proc. - aukštaji, o 43 - nebaigtą aukštaji (jie šiuo metu dar studijuoja). Apklausos klausimus galima suskirstyti i dvi grupes: 1) respondentu požiūris i užsienio kalbu mokymąsi ir ju mokymosi patirtis, 2) respondentu požiūris i ju asmenines galimybes toliau mokytis kalbu ir tandeminio mokymosi supratimas bei patrauklumas.

\section{Respondentų užsienio kalbų mokymosi patirtis ir požiūris i kalbų mokymąsi}

Apklausos atsakymu rezultatu analizè atskleidè, kad didžioji dauguma apklausoje dalyvavusiu respondentu moka dvi ar daugiau kalbu (žr. 1 pav.). Beveik pusè $(52,7$ \%) respondentu moka dvi užsienio kalbas. Tarp respondentu nebuvo né vieno, kuris nemoka jokios užsienio kalbos, o vienas respondentas moka net septynias kalbas.

Paklausti, kaip mokėsi užsienio kalbu, beveik visi respondentai nurodè mokykla, kolegija arba universiteta. Taip pat buvo paminèti kursai, privačios pamokos,

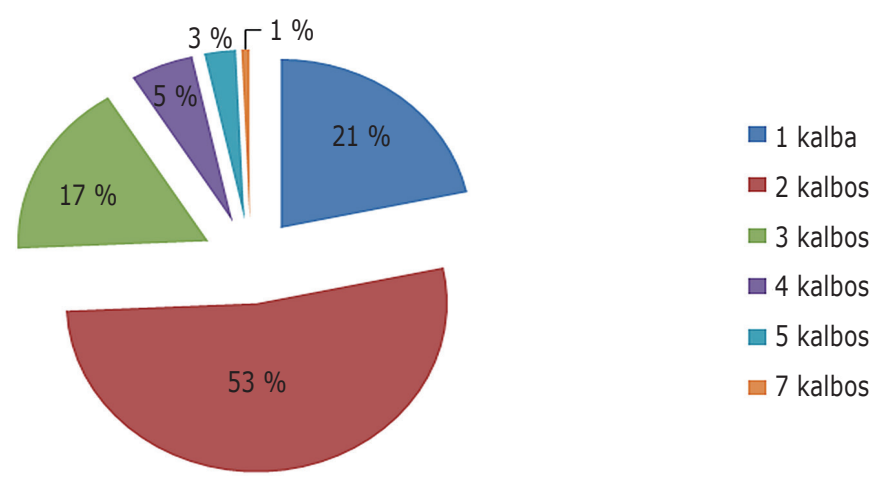

1 pav. Respondentų pasiskirstymas pagal mokamų užsienio kalbų skaičių

40 Prieiga internetu: http://apklausa.It/f/tandeminis-mokymasis-hkcs89u/answers/new.fullpage. 
gyvenimas užsienyje, filmu žiūrèjimas ir kt. (žr. 1 lentelę). Idomu pastebèti, kad net trečdalis (51) respondentu mokèsi užsienio kalbos (-u) savarankiškai ir tik vienas respondentas mokèsi su draugais užsieniečiais.

Respondentai galejo pasirinkti kelis atsakymu variantus, tad matyti, kad mokantis kalbu tenka išbandyti ne vieną būda, kol pasiekiamas norimas rezultatas.

\section{Užsienio kalbų mokymosi terpès}

\begin{tabular}{|l|c|}
\hline Užsienio kalbos (-u) mokymosi terpè & $\begin{array}{c}\text { Teigiamai atsakiusių } \\
\text { respondentų skaičius }\end{array}$ \\
\hline Mokykloje & 138 \\
\hline Kolegijoje / universitete & 130 \\
\hline Lankiau kursus & 16 \\
\hline Lankiau privačias pamokas & 19 \\
\hline Mokiausi savarankiškai & 51 \\
\hline Gyvenau užsienyje & 29 \\
\hline Iš šeimos nariu & 2 \\
\hline Kelioniu metu & 1 \\
\hline Žiūrèdama (-as) filmus & 1 \\
\hline Iš draugu užsieniečiu & 1 \\
\hline
\end{tabular}

Apklausoje dalyvaujantiems asmenims priimtiniausia mokytis užsienio kalbu grupejje ir privačiai, gerokai retesnis yra savarankiškas mokymasis. Respondentai pateikè ir savu variantu, kaip galima mokytis kalbu. Tarp atsakymu buvo aprašytas pavyzdys, atitinkantis tandeminio mokymosi apibrèžimą (žr. 2 lentelę).

\section{Užsienio kalbu mokymosi būdai}

\begin{tabular}{|l|c|}
\multicolumn{1}{|c|}{ Priimtini užsienio kalbų mokymosi būdai } & $\begin{array}{c}\text { Teigiamai atsakiusių } \\
\text { respondentu skaičius }\end{array}$ \\
\hline Mokymasis grupeje & 83 \\
\hline Privati pamoka & 82 \\
\hline Savarankiškas mokymasis & 49 \\
\hline Mokymasis mažose grupelèse & 1 \\
\hline Priimtini ̨̇vairūs būdai & 1 \\
\hline $\begin{array}{l}\text { Mokymasis kartu su tos pilietybės asmenimis, pvz., italu kalbą mokytis } \\
\text { kartu su italu (-e) }\end{array}$ & 1 \\
\hline Praktinis, kada reikia daug bendrauti su tos šalies žmonėmis & 1 \\
\hline
\end{tabular}


Respondentu taip pat buvo klausiama, kas jiems asmeniškai trukdo mokytis užsienio kalbu. Tarp atsakymu labiausiai išryškèjo laiko bei pinigu stoka ir nesèkminga ankstesnè mokymosi patirtis (žr. 3 lentelę).

\section{Priežastys, kliudančios mokytis kalbu}

\begin{tabular}{|l|c|}
\hline Priežastys, kliudančios mokytis kalbu & $\begin{array}{c}\text { Teigiamai atsakiusiu respondentu } \\
\text { skaičius }\end{array}$ \\
\hline Neturiu laiko & 100 \\
\hline Neturiu pinigu & 50 \\
\hline Nèra poreikio & 12 \\
\hline Nenoriu & 4 \\
\hline Iki šiol nesisekè mokytis kalbu & 24 \\
\hline Dėstytoju nekompetentingumas & 1 \\
\hline Neturiu kantrybės, kompleksuoju kalbejdamas & 1 \\
\hline Trūksta motyvacijos & 2 \\
\hline Neturiu gero mokytojo ir patogios vietos mokytis mokykloje & 1 \\
\hline Kalbas, kurias galiu sutikt kasdieniname gyvenime, jau moku & 1 \\
\hline
\end{tabular}

Trys respondentai atsakè labai pozityviai: „Mokytis kalbu niekas netrukdo ir tam visada yra laiko."

Paklausti, kokios priežastys skatina arba paskatintu mokytis užsienio kalbu, respondentai pateikè daugybę variantu (žr. 4 lentelę). Labiausiai išryškẻjo supratimas, kad užsienio kalbos prireiks profesinejje veikloje.

Atsakymai taip pat patvirtino stereotipini požiūri, kad kalbos atveria duris ì pasauli per kultūra, knygas, filmus, bendravimą su kitataučiais. Daugelio respondentu nuomone, kiekvienas žmogus privalo mokèti kelias užsienio kalbas.

\section{Kalbų mokymąsi skatinančios priežastys}

\begin{tabular}{|l|c|}
\hline Kalbų mokymąsi skatinančios priežastys & $\begin{array}{c}\text { Teigiamai atsakiusių respondentu } \\
\text { skaičius }\end{array}$ \\
\hline Kiekvienas žmogus privalo mokèti kelias užsienio kalbas & 92 \\
\hline Tai idomus laisvalaikio praleidimo būdas & 35 \\
\hline Tada galėsiu skaityti knygas, naujienas, žiūrèti filmus originalo kalba & 103 \\
\hline Savo profesinejje veikloje privalau mokèti užsienio kalbą & 4 \\
\hline Užsienio kalbos turiu mokytis dèl šeimyniniu aplinkybiu & 41 \\
\hline Noriu išvažiuoti gyventi i užsieni & 6 \\
\hline Lengviau bendrauti su kitataučiais & 1 \\
\hline $\begin{array}{l}\text { Manau, kad jeigu jau pradejau kažko mokytis, tai reikia padaryti iki } \\
\text { galo. Kažkada tikrai pravers. }\end{array}$ & 1 \\
\hline Lavina atminti & 1 \\
\hline $\begin{array}{l}\text { Daug idomiau bendrauti su žmogumi akis i aki ir per ji pažinti kultūrą. } \\
\text { Taip bendrauti galima tik mokant kalbą. }\end{array}$ & 1 \\
\hline
\end{tabular}


Respondentu buvo prašoma pateikti nuomonę apie svarbiausius veiksnius mokantis kalbos. Tarp atsakymu išryškejjo kelios grupès (žr. 5 lentelę). Pirma, respondentams svarbiausi dalykai yra žmogiški: motyvacija ir mokytojo kompetencija. Ne mažiau svarbios mokymosi aplinkybès, t. y. mokymosi laikas, medžiaga, grupès dydis, kursu vieta ir kaina. Trečioje vietoje tandeminiam mokymuisi priskiriamos savybès: besimokančiojo autonomiškumas, mokymosi medžiagos autentiškumas, gimtakalbis mokytojas (iš dalies tandeminio mokymosi savybè). Atsižvelgiant i tokius negausius atsakymus galima daryti prielaida, kad šie dalykai respondentams nèra svarbūs. Gali būti, kad jie nebuvo aiškiai suprasti, nes apie juos mažiau girdima, o mokantis šie elementai ne visada akcentuojami.

5 lentelè

\section{Svarbiausi kalbų mokymąsi lemiantys veiksniai}

\begin{tabular}{|l|c|}
\hline Svarbiausi veiksniai kalbu mokymesi & $\begin{array}{c}\text { Teigiamai atsakiusių respondentu } \\
\text { skaičius }\end{array}$ \\
\hline Motyvacija & 133 \\
\hline Mokytojo kompetencija & 114 \\
\hline Mokymosi medžiaga & 96 \\
\hline Laikas & 84 \\
\hline Pamoku / kursu kaina & 68 \\
\hline Grupės dydis & 65 \\
\hline Pamoku / kursu vieta & 42 \\
\hline Besimokančiojo autonomiškumas & 26 \\
\hline Mokymosi medžiagos autentiškumas & 19 \\
\hline Mokytojas turi būti gimtakalbis & 18 \\
\hline
\end{tabular}

\section{Tandeminio mokymosi supratimas ir patrauklumas}

Antraja grupę sudarė klausimai apie tandemini mokymąsi ir jo perspektyvas Lietuvoje bei respondentu paskatas mokytis naujos užsienio kalbos arba tobulinti jau turimus užsienio kalbos igūdžius apskritai ir tandeminiu būdu.

Respondentai atsakè i penkis klausimus, susijusius su ju norais mokytis užsienio kalbu. Klausimai ir respondentu atsakymai yra pateikti 6 lentelèje.

\section{Apklausos apie tandemini mokymąsi ir paskatas mokytis užsienio kalbų rezultatai}

6 lentelè

\begin{tabular}{|c|l|c|c|c|}
\hline \multicolumn{1}{|c|}{ Klausimai } & Taip & Ne & Nežinau \\
\hline 1. & Ar norètumète patobulinti turimas užsienio kalbu žinias? & $\begin{array}{c}144 \\
(96,6 \%)\end{array}$ & $\begin{array}{c}1 \\
(0,7 \%)\end{array}$ & $\begin{array}{c}4 \\
(2,7 \%)\end{array}$ \\
\hline 2. & Ar norètumète išmokti nauja užsienio kalbą? & $\begin{array}{c}133 \\
(89 \%)\end{array}$ & $\begin{array}{c}8 \\
(5,5 \%)\end{array}$ & $\begin{array}{c}8 \\
(5,5 \%)\end{array}$ \\
\hline
\end{tabular}




\begin{tabular}{|c|c|c|c|c|}
\hline & Klausimai & Taip & $\mathrm{Ne}$ & Nežinau \\
\hline 3. & $\begin{array}{l}\text { Ar tobulintumète savo užsienio kalbos (kalbu) žinias, jeigu } \\
\text { būtu galimybe mokytis kartu su gimtakalbiu nemokamai ir } \\
\text { Jums patogiu metu? }\end{array}$ & $\begin{array}{c}141 \\
(94,5 \%)\end{array}$ & - & $\begin{array}{c}8 \\
(5,5 \%)\end{array}$ \\
\hline 4. & $\begin{array}{l}\text { Ar mokytumètès kalbos, jeigu būtu galimybė mokytis kartu } \\
\text { su gimtakalbiu nemokamai ir Jums patogiu metu? }\end{array}$ & $\begin{array}{c}133 \\
(89 \%)\end{array}$ & $\begin{array}{c}3 \\
(2 \%)\end{array}$ & $\begin{array}{c}13 \\
(9 \%)\end{array}$ \\
\hline 5. & $\begin{array}{l}\text { Ar mokytumètès užsienio kalbos (arba tobulintumète } \\
\text { turimas žinias) tandeminiu būdu (poroje su gimtakalbiu, } \\
\text { Jums patogiu metu ir pasirinktu būdu (susitikus gyvai } \\
\text { ar elektroninèmis priemonémis), kai pusę pamokos } \\
\text { bendraujate užsienio kalba, o kitą pusę - Jūsu gimtaja } \\
\text { kalba)? }\end{array}$ & $\begin{array}{c}131 \\
(88 \%)\end{array}$ & $\begin{array}{c}3 \\
(2 \%)\end{array}$ & $\begin{array}{c}15 \\
(10 \%)\end{array}$ \\
\hline
\end{tabular}

Kaip matyti iš lentelès, klausimai buvo pateikiami nuo aptakiu iki labai detaliu, laipsniškai formuluojant tandeminio mokymosi apibrèžimą apimanti klausimą (Nr. 5). Žvelgiant i respondentu atsakymus, matyti, kad dauguma norètu toliau tobulinti turimas užsienio kalbu žinias. Išmokti nauja užsienio kalbą norètu šiek tiek mažiau respondentu. Tą būtu galima paaiškinti tuo, kad dauguma respondentu moka daugiau negu vieną kalbą. Kita vertus, ryžtis mokytis naujos kalbos yra sudètingiau negu tęsti jau pramoktos kalbos studijas.

Suformulavus klausimą apie mokymąsi tandemu, pastebimas nežymus teigiamu atsakymu sumažejjimas ir abejojančiuju padaugejjimas. Anketoje ties šiuo klausimu ne vienas respondentas parašè komentara, kad neaišku, kas yra tandeminis mokymosi būdas. Tai ir galèjo turèti itakos didesniam neapsisprendusiuju skaičiui. Vienas respondentas pakomentavo, kad mokantis kalbos nèra tikslo pusę pamokos bendrauti jo / jos gimtaja kalba, nes taip mažiau išmoksi užsienio kalbos. Tad galime daryti prielaida, kad tandeminis kalbu mokymosi metodas nèra žinomas. Tokia prielaida patvirtino ir atsakymai i vieną pirmuju apklausos klausimu, ar respondentai žino, kas yra tandeminis kalbu mokymasis (žr. 2 pav.).

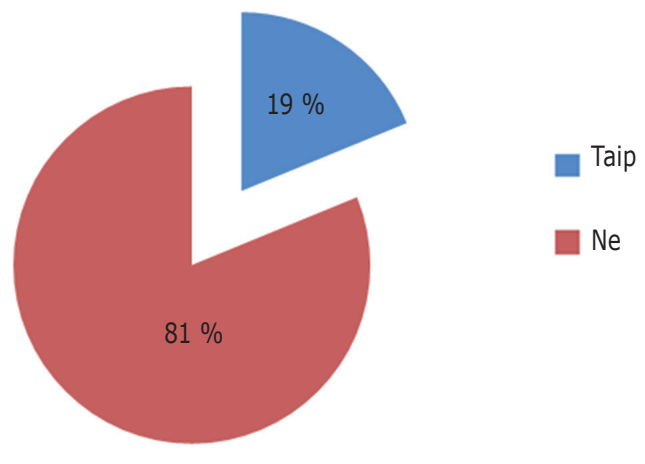

\section{2 pav. Respondentų pasiskirstymas pagal ju turimą informaciją apie tandemini mokymąsi}

Kaip matyti iš paveikslo, tik $19 \%$ (28 respondentai) žino, kas yra tandeminis kalbu mokymasis. Šie rezultatai siejasi ir su paskutiniu klausimu apie tandeminio mokymosi perspektyvas Lietuvoje (žr. 3 pav.). 


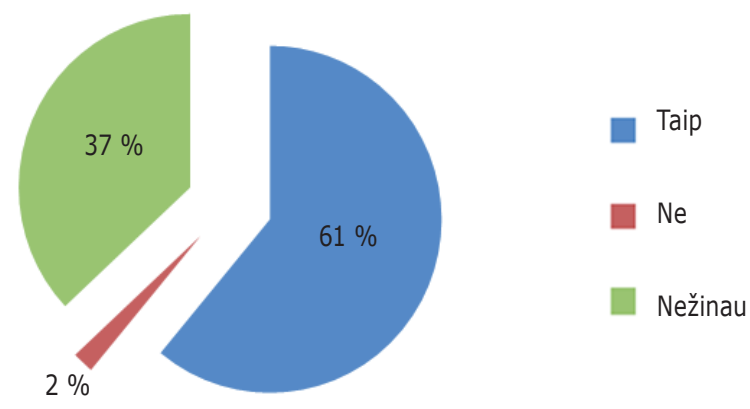

3 pav. Respondentų nuomonè apie tai, ar tandeminis mokymasis turi šansu išpopuliarèti Lietuvoje

Daugiau negu pusè respondentu tiki tandeminio mokymosi sèkme Lietuvoje, trečdalis ja abejoja. Keletas respondentu pakomentavo savo atsakymus teigdami, kad šis metodas mažai žinomas, kad būtu sunku susirasti gimtakalbi tandemo partneri ir neaišku, kiek užsieniečiu norètu bendradarbiauti.

Respondentu išsakytai dvejonei galima iš dalies pritarti, nors ivairios komunikacijos technologijos suteikia galimybę bendrauti su kitataučiais ne tik Lietuvoje, bet ir visame pasaulyje. Nelabai aišku, ar būtu ir kiek būtu užsieniečiu, norinčiu mokytis nedidelès ir ekonomiškai nelabai stiprios šalies kalbos. Reikètu pasvarstyti, o gal net atlikti preliminarius tyrimus, kokios užsieniečiu grupès būtu suinteresuotos mokytis lietuviu kalbos. Greičiausiai be kalbu entuziastu, poliglotu ir kalbininku, lietuviu kalbos galètu mokytis su Lietuva bendradarbiaujantys užsienio verslininkai, imigrantai, siekiantys isikurti Lietuvoje, baltistikos studiju studentai užsienyje, studentai užsieniečiai Lietuvoje, lietuviu išeivijos atstovai ir kt.

\section{Išvados}

Straipsnyje, remiantis užsienio literatūra, išsamiai pristatomas tandeminis užsienio kalbu mokymosi metodas: apibréžiami svarbiausi jo elementai (tandemo partneriu vaidmuo, užsièmimu forma, medžiaga), aptariami pagrindiniai principai (autonomiškumas ir abipusiškumas), svarstoma, kokias kompetencijas ugdo šis metodas (užsienio kalbos, savo gimtosios kalbos, tarpkultūrinès komunikacijos, mokymosi bendradarbiaujant, mokymosi mokytis ir kt.).

Tandeminio mokymosi metodas yra gana naujas. Siekiant išsiaiškinti, kokios yra jo perspektyvos Lietuvoje, buvo atlikta apklausa. Pirmosios apklausos dalies klausimai suteikè žiniu apie respondentus ir atskleidè ju požiūri i užsienio kalbu mokymąsi. Dauguma apklausoje dalyvavusiu respondentu moka dvi ar daugiau kalbu, užsienio kalbu mokèsi daugiausia mokykloje, kolegijoje arba universitete. Taigi, galima teigti, kad respondentai turi užsienio kalbu mokymosi patirties, o ju nuomonė apie kalbu mokymąsi yra aktuali ir reikšminga. Anot respondentu, geriausia kalbu mokytis yra grupeje arba privačiai. Tarp priežasčiu, trukdančiu mokytis užsienio kalbu, respondentai dažniausia nurodè laiko bei pinigu trūkumą ir nesėkmingą ankstesnę mokymosi patirti. Respondentu nuomone, labiausiai mokytis kalbu juos skatina arba paskatintu būtinybè vartoti užsienio kalbą profesinèje veikloje. Kalbu mokèjimas taip 
pat naudingas asmeninejje srityje: bendraujant su užsieniečiais, skaitant knygas, žiūrint filmus, keliaujant. Pagal respondentu atsakymus išsiskyrè trys veiksniu, kurie turi itakos kalbos mokymuisi, grupès: svarbiausia yra motyvacija ir mokytojo kompetencija, mokymosi aplinkybès (laikas, vieta, kaina, grupès dydis), tandeminio mokymosi ypatybės (besimokančiojo autonomiškumas, mokymosi medžiagos autentiškumas ir gimtakalbis mokytojas) nèra tokios svarbios.

Antrojoje apklausos dalyje respondentai atsakè i klausimus apie ju paskatas mokytis kalbos arba tobulinti užsienio kalbos igūdžius apskritai ir tandemu bei tademinio mokymosi perspektyvas Lietuvoje. Esminiai skirtumai tarp noro patobulinti arba išmokti naują užsienio kalbą apskritai ir tandemu neišryškejjo. Beveik visi respondentai norètu patobulinti turimas užsienio kalbu žinias, tačiau mokymasis tandemu neatrodo labai patrauklus (pastebètas nežymus teigiamu atsakymu sumažejjimas ir abejojančiuju padaugejjimas). Viena iš priežasčiu yra ta, kad daugeliui nebuvo aišku, kas yra tandeminis mokymasis (tą liudija respondentu komentarai). Tik penktadalis respondentu atsakẻ žina, kas yra tandeminis mokymasis.

Nors remiantis apklausos duomenimis pats metodas neatrodo labai žinomas, griežtos išvados apie menkas tandeminio mokymosi perspektyvas Lietuvoje daryti negalima. Pirma, daugiau negu pusè respondentu vis tik mano, kad tandeminis kalbu mokymasis turi galimybiu išpopuliarèti Lietuvoje. Antra, šio metodo žinomumas tèra pastangu ir laiko klausimas. Trečia, apklausos rezultatus ir išvadas galejo nulemti pasirinktas tyrimo metodas. Respondentai suprato ne visas klausimy formuluotes, 0 i klausimus atsakant internetu nebuvo galimybès respondentui paaiškinti klausima. Formuluojant klausimus galejo būti praleisti respondentams svarbūs atsakymai, kuriu jie patys nepanorèjo irašyti. Paradoksalu, tačiau apklausos internetu patogumas yra ir tokio tyrimo apribojimas, mat nuoroda j apklausa yra vienintelis paraginimas dalyvauti apklausoje. Apklausos rezultatai galèjo būti kitokie, jeigu joje būtu dalyvavę daugiau respondentu.

Siekiant populiarinti tandemini kalbu mokymąsi, reikètu pirmiausia nustatyti, kurios kalbu vartotoju / besimokančiuju grupès būtu suinteresuotos mokytis lietuviu kalbos ir bandyti ivairiais būdais tai pasiekti.

\section{Literatūra}

Alonso, A. C. (2012). Promoting basic competences in EFL instruction by means of e-mail tandem. Journal of Language Teaching and Research, 3(2), 232-238. DOI: 10.4304/ jltr.3.2.232-238.

Appel, C., \& Mullen, T. (2000). Pedagogical considerations for a web-based tandem language learning environment. Computers \& education, 34, 291-308.

BABELYOU. Prieiga internetu: http://www.babelyou.com/.

Brammerts, H. (1996). Tandem language learning via the Internet and the International E-Mail.

Donaldson, R. P., \& Kötter, M. (1999). Language learning in a MOO: creating a transoceanic bilingual virtual community. Literary and linguistic computing, 14(1), 67-76.

International Tandem Network. Prieiga internetu: http://www.cisi.unito.it/tandem/email/ idxeng00.html. 
Kabata, K., \& Edasawa, Y. (2011). Tandem language learning through a cross-cultural keypal project.

Kawaguchi, S., \& Di Biase, B. (2009). Aligning second language learning and computer-assisted language learning: networking the language class, tandem learning and e-movies. The International Journal of Learning, 16(10), 287-302.

Language learning and technology, 15(1), 104-121. Prieiga internetu: http://lt.msu.edu/issues/ february2011/kabataedasawa.pdf.

Little, D. (1996). Learner autonomy and learner councelling. In D. Little and H. Brammerts (Eds.) A guide to language learning in tandem via the Internet. CLCS occasional paper No. 46. (p. 23-34). Dublin: Trinity College.

Little, D., \& Brammerts, H. (1996). A guide to language learning in tandem via the Internet. CLCS occasional paper No. 46. Dublin: Trinity College.

O'Rourke, B. (2005). Form-focused interaction in online tandem learning. CALICO Journal, 22(3), 433-466.

Polisca, E. (2011). Language learning and the raising of cultural awareness through Internet telephony: a case study. The Language Learning Journal, 3(9), 329-343.

SEAGULL. Projekto oficialus tinkalapis. Prieiga internetu: http://seagull-tandem.eu/.

Stickler, U. (2008). Chatting, chatten or chattare: using a multilingual workplace for language and culture learning. IJET, 3, Special issue 3: "ICL2008”, 69-76. DOI: 10.3991/ijet. v3il.731.

Tandem City. Prieiga internetu: http://www.tandemcity.com/.

Tandem Network. In D. Little and H. Brammerts (Eds.) A guide to language learning in tandem via the Internet. CLCS occasional paper No. 46. (p. 9-22). Dublin: Trinity College.

Tandem-Server Bochum. Prieiga internetu: http://www.slf.ruhr-uni-bochum.de/.

Vassallo, M. L., \& Telles, J. A. (2006). Foreign language learning in-tandem: theoretical principles and research perspectives. The ESPecialist, 25(1), 1-37.

\section{Jurgita Cvilikaitè}

Vytautas Magnus University, Lithuania; j.cvilikaite@uki.vdu.It

\section{LANGUAGE LEARNING IN TANDEM: ELEMENTS, PRINCIPLES AND PERSPECTIVES}

Summary. The article describes the method of tandem learning and defines its key elements - the roles of tandem partners, the form of learning sessions and learning material. Tandem language learning takes place between two native speakers who are learning each other's language. Based on the principles of autonomy and reciprocity, the method provides a different way of learning a foreign language, where the process is organised and planned solely through collaboration between tandem partners. While learning in tandem, they improve foreign and native language knowledge and develop intercultural communication, learning in collaboration, learning to learn and other important competences. The article presents the results of a survey which was designed to find out whether tandem learning is known in Lithuania. The survey also reavealed the apeal of tandem learning to the respondents. It was interesting to know how many respondents would be motivated to improve foreign language skills or to start learning a new language via tandem learning. The results of the survey show that only one fifth of the respondents knows the concept of tandem learning and more than a third doubts that this method could become popular in Lithuania. However a majority of the respondents would agree to learn in tandem. The most acceptable learning methods for the respondents are learning in groups or privately. Individual 
learning was mentioned only by a minority of the respondents. Lack of time and money were the most popular among the factors hindering learning languages. The survey established that tandem learning is not well known in Lithuania and is rarely employed. Although it is claimed that tandem learning is more an auxilliary method, it would be useful both for language learners and scientists researching learners behaviour in various situations, motivation, learning achievements and other areas.

Keywords: tandem learning, tandem partners, autonomy, reciprocity, foreign language acquisition. 